\title{
Why should we be interested in the specificity of subjectivity and neoliberalism in Latin America?
}

\author{
Julián Medina-Zárate ${ }^{1}$ Flávia M. Uchôa de Oliveira²
}

Published online: 23 November 2019

(c) Springer Nature Limited 2019

Subjectivity has been an important and controversial concept for the social sciences and humanities as it has been defined and conceptualized from different perspectives. This might be considered a very well-known statement; after all, some of these debates constituted this very journal. Nevertheless, there are statements that we cannot take for granted and we must stress them whenever we have the chance. For instance, as critical psychologists, we must insist and emphasize the tensions rooted in the differences between epistemic and ontological comprehension about what we can know and how can we study subjectivity. We consider that one of the main challenges of critical work in psychology, social sciences and humanities is precisely the persistent reflection on these tensions.

That being the case, we might briefly present our perspective. We refuse the idea that subjectivity is an eternal substance or entity. Instead, we radically assume that subjectivity is constituted within history and culture, and that to study it is only possible in relation to different contexts and times (Henriques et al. 1998; Rose 1990, 1996). Subjectivity cannot correspond to a natural locus of a given psychological reality, and therefore, our research should pursue how the subjects are socially constituted (Rose 1990; Gómez Sánchez et al. 2006).

This is not only our perspective, in fact, since the 1960s, this perspective is the "message of studies from a variety of disciplines, which have pointed in different ways to the historical and cultural specificity of our modern western conception of the person" (Rose 1996), and it has had an impact on many forms of intervention in our social and political life (Blackman et al. 2008). Blackman et al. (2008) argue that recent work with respect to subjectivity has moved beyond discourse to incorporate experience, body and materiality within subjectivity, and even questioning of the concept of subjectivity itself. These shifts have brought the renewed importance of the cultural and social-political locatedness. In this sense, subjectivity, despite its fruitfulness for critical research, possesses no trans-historical validity and cannot

Flávia M. Uchôa de Oliveira

flavia.muo@gmail.com

1 School of Social Sciences, Cardiff University, Cardiff, UK

2 Social Psychology, University of São Paulo, São Paulo, Brazil 
lie beyond historical specificity. While the debates within the journal have covered a wide range of topics, they have tended to engage with contexts within the Global North. However, those approaches can miss the positionality, in terms of the global geopolitical organization, in which they are formulated. In this sense, this issue represents an opportunity to debate subjectivity from within a different geopolitical position, in which the reflections about the particularities of the Latin American context and history became relevant for understanding subjectivity in this region of the world, opening the door to alternative approximations to the subject such as postcolonial studies and decolonial thinking. These approaches are crucial not only to the debate of the concept of subjectivity but for decentralizing a eurocentralized knowledge (Grosfoguel and Castro-Gomez 2007).

From this point of view, historicity matters to the studies of subjectivity. On the one hand, there is no universal subject, but on the other, there is no specificity of subjectivity, as if we could discover something defined, particular, unusual or exotic about it, separating it from its own dynamic and not-identical constitution. Or, even more problematic, as if we could separate something 'exotic' to be compared with what is said to be the 'rule', denying difference. In this sense, the study of subjectivity must be located within the discontinuities of history, in a search for its folds. Or rather, as a Brazilian sociologist (Cardoso 2015) has insisted, we need to search for the knots that hold together ourselves as subjects, as well as the effects of our constitution as subjects. He argues that, for instance, the colonization of Latin America has an impact on our lives as Latin Americans, however, it has equally an effect on Europe and its population. In this two-way argument he seeks to emphasize the knots that bring together the constitution of Latin America and Europe, refusing to acknowledge an exoticism or an exceptionality in this process (Cardoso 2015). Therefore, we propose that subjectivity must be understood as historicity interwoven.

Thus, to study subjectivity and neoliberalism in Latin America is to aim precisely at a knot that holds together a normative system possessed of a certain efficiency to direct states, enterprises and subjects in our continent. In this sense, to study Latin American subjects in times of global neoliberalism implies pulling together the differences that constitute the political and economic history of the continent and the set of relationships that makes possible the emergence of local and diverse ways of existing in the territory.

As a departure point, it is necessary to define what neoliberalism is for the purpose of these reflections. As Cahill et al. (2018) have signalled, the use of the term neoliberalism-established among English-speaking scholars by David Harvey (2007)-remains extremely valuable because it represents "a political intervention from the left", especially from the Latin American left, that is "a will to name and resist a set of forces that wished to present itself as ineluctable, without alternative, and thus not open to resistance". Although neoliberalism does not have a unanimous use or definition, and still is a highly debated term among scholars, it is important to insist in its discussion as a way of creating other alternative routes for understanding the present.

While some would define neoliberalism as an ideology, others will affirm that it is a governmentality, or yet, will describe it as an economic mechanism or a mode 
of production. Although these are different approaches to the understanding of neoliberalism, they have similarly defined it as a pro-market and pro-corporate regime. Moreover, these approaches also share a geopolitical perspective: the North origin narrative of neoliberalism. This means neoliberalism is usually understood as the road created from Mont Pèlerin (Mirowski and Plehwe 2015), with the gathering of "anti-communist economists in Europe and the United States in creating a theory exalting free markets", and being put into political use by Margaret Thatcher and Ronald Reagan in the beginning of 1980s, when "a wave of monetarist policy, privatization, deregulation, tax reduction and attacks on welfare-state 'entitlements' followed". Finally, through the political power of the North, neoliberalism was imposed on the rest of the globe (Dados and Connell 2018).

Nevertheless, that narrative neglects important historical facts. For instance, it is often forgotten that neoliberal policy in Latin America was inaugurated in Chile, by state terrorism, dictatorship, and profound economic reform led by Augusto Pinochet and, at a certain point, the "Chicago Boys". In fact, the famous document that oriented the economic shift during the dictatorship_ 'El ladrillo' ('The Brick') ${ }^{1}$ was developed in1956 with the partnership between Pontificia Universidad Católica de Santiago de Chile and the Chicago School of Economics. Hence neoliberalism was being also forged theoretically from the late 1950s by Latin American academics in partnership with US colleagues. However important, this academic link with Chicago is not able to explain all the reasons why Pinochet would use "an economic ideology not at the time mainstream in the United States" (Connell and Dados 2014). What neoliberalism offered to the Chilean dictatorship was much more than an economic theory, it was an answer to its political problem that was (1) "how to get legitimacy by economic growth"- - economic growth which, as Celso Furtado (1974) explained, is not the same as development; (2) "satisfy his backers in the Chilean propertied class"; and (3) "keep the diplomatic support of the United States, without giving an opening to his opponents in the political parties and labour movement" (Connell and Dados 2014).

Here, we can find a tension between the most common narrative about neoliberalism and the development of neoliberal politics in Latin America, highlighting the deep links between this political agenda and the continent, which date almost thirty years before the elections in which Thatcher became Prime Minister of the United Kingdom and Reagan became the President of the United States, both considered to be the bastions of neoliberalism; and forty years before than the Washington Consensus - a ten-point document established as a recommendation to Latin America which included privatization, deregulation, trade liberalization, controlling deficit spending, and cuts in social welfare (Kingstone 2018).

\footnotetext{
1 'The brick' or 'El Ladrillo' was first published as Programa de desarollo económico (Economic Development Programme) in 1973. In 1992, it was reprinted as 'El Ladrillo': Bases de la Politica Económica del Gobierno Militar Chileno, Centro de Estudios Publicos', with preface by Sergio de Castro. It presents an evaluation and a market-based development strategy regarding education, labour, agriculture and industry. The document in Spanish is available at http://www.memoriachilena.gob.cl/archivos2/pdfs/ mc0032306.pdf (accessed on November 2019).
} 
However, why should a reconsideration of the narratives of the origins of neoliberalism be important to the study of subjectivity in the continent? First, unlike the European version of dismantling the 'Nanny State', neoliberalism in Latin America was promoted to contest other elements and strategies. According to Dados and Connell (2018), for instance, two of these contested strategies by neoliberals were the capitalist import-replacement industrialization (IRI) and local industrialization. This demonstrates that the 'reason for existence' of the neoliberal agenda in Latin America is different from the narrative merely centred on "the brains of Northern economists" or on the idea of an answer to "an economic crisis internal to the global North" (Connell and Dados 2014).

Additionally, development of neoliberal politics in Latin American territory during the mid-twentieth century was carried by social groups and economic elites from those decades, who were different from the European and the United States political elites who positioned these policies in the focus of the global political agenda. As Connell and Dados (2014) point out, when local industrialization and import-replacement industrialization were demonstrated not to be competition against the industries of the economic potencies from the North Atlantic, the local elites shifted the strategy to a prioritization of the economic activities with the markets that were easier to exploit and to synchronize with the buoyant industries from the north, under the logic of "comparative advantage".

This shift in strategy resulted in the consolidation of extractive activities, such as mining and large-scale farming, as the main sources of production and labour, which was often underpaid and aggressively explored precarized rural workforce as a main "comparative advantage" in relation to the workers from the "first world" nations. Simultaneously, the local elites who renounced the industrialization of the Latin American economies, allied with the military and with transnational corporations, constituting an assemblage of political and economic forces which ended up guiding the development the neoliberal agenda and the installation of the neoliberal states in the continent a la tropical.

In contrast to the constitution of the European Welfare States, the processes of producing tropical capitalist states was characterized by the proliferation of partisan politics and populism, incorporating practices of political violence and corruption. The local elites were usually inheritors or re-organizers of the colonial markets and commerce routes, hence, were also involved with social dynamics of the neo-colonial Latin America, where the feudal and the modern were mixed and coexisted in diverse ways at the time of constituting the capitalist states in the region.

Today, our states are still marked by colonial and neo-colonial history. Moreover, with the intensification of the neoliberal rationalities of governance by the end of the last century and the reduction of the presence of the state in the social and economic life, marginalized groups related to illegal economies had space to grow and empower themselves in the neoliberal states (Valencia 2010). This can be reflected in the links that many of the Latin American governments have shown with drug trafficking and paramilitary militias. Economically, this has been translated into high levels of informality, high levels of inequity and a productive apparatus, where the past and the present coexist, constituting a distinctive political and historic setting 
in where local identities are related to diverse and heterogeneous socio-economic contexts.

Returning to the idea of subjectivity as a space where the relationship between the social structure of power and social actors take place (Papadopoulos 2003), we can understand how the study of subjectivity in Latin America must consider the differences of the history of Neoliberalism in the continent and its complexities, which involve the different colonial and neo-colonial dynamics that built our nations and which are still operating as a heritage that continues to configure the political, social and economic life of Latin American communities.

In this sense, the perspective of Northern-centred narratives of neoliberalism can shift, for example, to promote renewed analyses about Labour and workers' subjectivities in our continent, less centred in the 1980s employment crisis, and combining other crucial elements such as the importance of the informal sector of the economy in our continent, the illegal economies that are recurrent in the region or the highly flexible and precarious conditions that characterize the Latin American labour market.

Regarding these issues, and in accordance with the contemporary trends in the world of work around the world, entrepreneurialism arises as a key line of study at the time of understanding subjectivity in the neoliberal global context. As Bröckling (2015) argues, today there is a demand for shaping society and the self, following the rationalities of entrepreneurship as a way of self and social governance. Latin America has not been the exception of this trend. Moreover, the region shows some of the highest levels of "entrepreneurialism" around the world according to the Global Entrepreneurship Monitor (GEM 2017). This trend opens further lines of study for understanding the local tropes of subjectivity that emerge within the Latin American contexts, which are characterized nowadays by the entrepreneurial demand that came into relation with the mode of fabrication of neoliberalism in the continent. Thus, rejecting the essentialist approach to subjectivity, the Latin American entrepreneurial subject-rather than a container of psychological essences-is produced within a complex set of relationships in which the new perspectives of labour came into dialogue with the neoliberal tradition in the continent, regarding all the differences highlighted above.

This question of the entrepreneurial subject in this region is key to understanding the relatively new modes of subjectivities that emerge in our continent, playing a central role in the dissemination and reproduction of the neoliberal rationalities. It can also be related to the question about alternatives and resistance to the threats and violence embedded in the neoliberal regimes of work and governance.

For instance, and particularly in relation to our research on entrepreneurialism in Latin America, this shift in understanding the origins of neoliberalism and its further development in the region, sheds light on how entrepreneurship is used as a rationale. First, it creates a sense of destiny in our continent, in which social inequalities are used as a form of education to strengthen the entrepreneurial self. Nevertheless, this entrepreneurial self is forged based on references of the North American and European entrepreneurs. Second, entrepreneurialism became the labour's "paradigm of modernization", promoting the idea that to achieve modernity and progress (understood as evolution), a society must be more "shaped by the North" entrepreneurial. Third, in 
contexts where violence and corruption are part of the power structures and daily life, entrepreneurship became an ambiguous figure as it can underpin both more violent and corrupt expressions, related to necropolitics (Mbembe 2006), or as a way of finding the alternatives that the states historically have not been able to, or even interested, in providing.

Finally, bringing those considerations to the current socio political events taking place across the continent, it is important to remember the past 20 years in Latin America, when we have seen the rise of the so-called "pink tide" period, inaugurated by the election of Hugo Chavéz in Venezuela, and succeeded with leftist parties governing almost half the continent, such as Evo Morales' government in Bolivia since 2006, the 10 years of Rafael Correa's government in Ecuador, and 12 years of Worker's Party government in Brazil. But we have also now a new swing to right wing from the end of the 2010s, with neoliberal prescriptions rising up again (Kingstone 2018). The election of far-right governments, especially in Brazil with the election of the conservative right wing Jair Messias Bolsonaro, after the institutional coup to impeach Dilma Rousseff, the arrest of Lula da Silva, and in Argentina, with the election of the businessman Mauricio Macri after Kirchner-Fernandez periods.

Nevertheless, at this very moment we are also seeing intense protests spreading across the continent, especially in Haiti, Ecuador and Chile among many others, motivated by the unreasonableness of the neoliberal policies in most cases. For instance, in the beginning of October this year, indigenous people, women's organisations, unions and students in Ecuador led the protests against the neoliberal policies recommended by the IMF and implemented by the government of Lenín Moreno. The labour reform and other policies were rolled back after 2 weeks of popular demand on the streets. In Chile, a $17 \%$ rise in metro fares provoked a massive insurrection of people led mostly by students on the streets of Santiago. There, despite the rolling back of the fare rise, the protests continue and are now targeting broader policies of Sebastián Piñera's government.

It seems that the image of the 'pendulum of history' cannot be easily applied to Latin America as we are in a constant struggle to create and lead our own way of living, not in backwards-forwards moves, but in convulsions, dealing with the inequalities that constitute us and the with the global capitalist demand to 'develop'.

To conclude, we must say that these few words are an effort to invite the readers to explore the ideas and reflections presented in this issue. And, above all, an effort to instigate curiosity in the pluriversality of subjectivity, decentering and provoking new ways of thinking about subject, history and culture. We consider this special issue on subjectivity and neoliberalism in Latin America as a significant tool that enables us with a contextualized comprehension of the subjects in our continent within the current geopolitical and economic order. We hope that the readers take advantage of it, and, most of all, advance on the creation of new possibilities. 


\section{References}

Blackman, L., J. Cromby, D. Hook, et al. 2008. Creating subjectivities. Subjectivity 22 (1): 1-27. https:// doi.org/10.1057/sub.2008.8.

Bröckling, U. 2015. The entrepreneurial self: Fabricating a new type of subject. London: Sage.

Cardoso, A. 2015. A construção da sociedade do trabalho no Brasil. Rio de Janeiro: Editora FGV.

Cahill, D., M. Cooper, M. Konings, and D. Primrose. (Eds.). 2018. The SAGE handbook of neoliberalism. Sage.

Connell, R., and N. Dados. 2014. Where in the world does neoliberalism come from? The Market Perspective in Southern Perspective 43 (2): 117-138.

Dados, N., and R. Connell. 2018. Neoliberalism in world perspective: Southern origins and southern dynamics. In The SAGE handbook of neoliberalism, ed. D. Cahill, M. Cooper, M. Konings, and D. Primrose, 28-39. London: Sage.

Harvey, D. 2007. A brief history of neoliberalism. Oxford: Oxford University Press.

Foucault, M. 1982. The subject and power. Critical inquiry 8 (4): 777-795.

Furtado, C. 1974. O Mito do Desenvolvimento Econômico. Rio de Janeiro: Paz e Terra.

Global Entrepreneurship Monitor. 2017. GEM 2015/2016 Latin America and Caribbean Regional Report-Spanish. Recovered from https://www.gemconsortium.org/report/49822.

Gómez Sánchez, Lucía, Luz M. Martínez Martínez, Jódar Rico, and Francisco Jódar Rico. 2006. Psicologia, identidade e política nas tecnologias de governo neoliberais. Psicologia \& Sociedade 18 (1): 7-14. https://doi.org/10.1590/S0102-71822006000100002.

Grosfoguel, R., and S. Castro-Gomez. 2007. El giro decolonial. Reflexiones para una diversidad. Bogota: IESCO-Pensar-Siglo del Hombre.

Henriques, J., W. Hollway, C. Urwin, C. Venn, and V. Walkerdine. 1998. Changing the subject: Psychology, social regulation, and subjectivity. London: Psychology Press.

Kingstone, P. 2018. The rise and fall (and rise again?) of Neoliberalism in Latin America. London: Sage. Mbembe, A. 2006. Necropolitics. Raisons politiques 1: 29-60.

Mirowski, P., and D. Plehwe (eds.). 2015. The road from Mont Pèlerin. Cambridge, MA: Harvard University Press.

Papadopoulos, D. 2003. The ordinary superstition of subjectivity: Liberalism and technostructural violence. Theory \& Psychology 13 (1): 73-93.

Rose, N. 1990. Governing the soul: The shaping of the private self. Florence, KY: Taylor \& Frances/ Routledge.

Rose, N. 1996. Power and subjectivity: Critical history and psychology. In Historical dimensions of psychological discourse, ed. C.F. Graumann and K.J. Gergen, 103-124. Cambridge: Cambridge University Press.

Valencia, S. 2010. Gore Capitalism, vol. 24. Cambridge: MIT Press.

Publisher's Note Springer Nature remains neutral with regard to jurisdictional claims in published maps and institutional affiliations.

Julián Medina-Zárate is currently a Ph.D. candidate in the School of Social Sciences at Cardiff University, UK, under the supervision of the Professor Valerie Walkerdine. In addition, he has been part of the research group 'Critical Studies of Work and Organisations' at Pontifical Xavierian University, Colombia, which is registere in COLCIENCIAS.

Flávia M. Uchôa de Oliveira is a Ph.D. candidate in Social Psychology at University of São Paulo, Brazil under the supervision of Professor Leny Sato. As part of this, she undertook a sandwich programme at Cardiff University, supervised by Professor Valerie Walkerdine. In addition, she is a member of the Work, Social Movements and Social Public Policies Research Group (TraMPoS) at University of São Paulo. 